\title{
En tenåring med smerter, dobbeltsyn og ustø gange
}

\author{
En tidligere frisk jente utviklet progredierende lammelser og sensibi- \\ litetsforstyrrelser. Hun responderte ikke på behandling, og differensial- \\ diagnosene var mange. Årsaken til pasientens symptomer skulle vise \\ seg å være langt fra vanlig.
}

En jente i begynnelsen av tenårene fikk smerter $i$ tennene og kjeven. Hun kontaktet tannlegen, som konkluderte med friske tenner. Få dager senere utviklet jenta også ryggsmerter. Hun kontaktet fastlegen som oppfattet smertene som muskulære. Behandling i form av smertestillende medisiner gjorde jenta smertefriallerede samme dag og effekten vedvarte i et par dager. Jenta hadde vært smertefri $i$ to dager da hun i løpet av noen timer utviklet dobbeltsyn og ustø gange i slik grad at hun trengte støtte for å gå. Fastlegen ble kontaktet på nytt, og klinisk undersøkelse avdekket anisokori, nyoppstått dobbeltsyn og ustøhet ved gange. Jenta ble henvist til barneavdelingen for øyeblikkelig hjelp.

Ved innkomst var jenta engstelig, men klar og orientert. Hun hadde ikke hodepine eller andre smerteplager og var afebril uten nakkestivhet. Orienterende nevrologisk undersøkelse avdekket anisokori med mydriasis og minimal lysreaksjon av venstre pupill samt horisontal diplopi spesielt ved blikkretning mot venstre. Man fant normal motilitet og sensibilitet $i$ ansiktet. Det var normale kraftprestasjoner og normale dype senereflekser i over-og underekstremiteter, med bilateralt nedadvendt plantarreflekser. Pasienten beskrev nummenhetsfølelse distalt $i$ alle fire ekstremiteter. Hun hadde normal gangfunksjon, men følte seg ustø. Man fant ingen ataksi eller dysdiadokokinesi.

Pasienten ble innlagt med nyoppståtte nevrologiske symptomer. Det var ingen risikofaktorer for tromboembolisk sykdom eller intracerebral blødning i sykehistorien, slik som bruk av p-piller eller hodetraume. Uten feber, nakkestivhet og hodepine var det lav klinisk mistanke om forhøyet intrakranialt trykk, purulent meningitt eller encefalitt. Både symptomer og funn gjorde at vi først og fremst mistenkte sentralnervøs årsak. I første omgang ønsket vi bildediagnostikk for å se etter intrakranial patologi. Deretter var det aktuelt å analysere spinalvæsken med tanke på eventuell infeksjon og/eller inflammasjon.

Vi valgte å unngå unødig strålebelastning med CT-undersøkelse og rekvirerte MR caput direkte. Denne avdekket ingen patologi. Orien- terende blodprøver med elektrolytter, blodglukose, hemoglobin og røde og hvite blodceller med differensialtelling var alle normale og $C R P$ var 0 (0-10 mg/l). Spinalpunksjon viste svakt gul spinalvæske, mononukleær pleocytose med 351 celler ( $\leq 4$ celler/ $\mu$ l), forhøyet protein på 2,11 (0,15-0,45 g/l) og normal glukose. Spinalvæske ble sendt til analyse for Epstein-Barr-virus, enterovirus, herpes simplex-virus, varicella zoster-virus og bakterier. Det ble tatt serum- og spinalvæskeprøver for borreliaantistoff og antiglutamat samt serumprøve for gangliosidantistoff (GQ1b-antistoff). Behandling ble startet med intravenøs ceftriakson grunnet mistanke om nevroborreliose, og intravenøs aciklovir for å dekke muligheten for herpesencefalitt.

På dette tidspunkt ble nevroborreliose ansett som den mest sannsynlige diagnosen. Pasienten hadde ikke registrert flåttbitt, men var ofte i skog og mark. Spinalvæskefunn med pleocytose og hyperproteinemi trakk i retning av infeksiøs etiologi, men en autoimmun reaksjon kunne ikke utelukkes. Derfor ble pasienten testet for antiglutamat med tanke på anti-N-metyl-D-aspartatreseptor (NMDA)-encefalitt, som er en autoimmun, ofte paraneoplastisk tilstand som kan ramme unge kvinner (1-3). Vi vurderte også MillerFishers syndrom, som er en variant av Guillain-Barrés syndrom som karakteriseres av oftalmoplegi, ataksi og arefleksi (4-7). Vår pasient hadde oftalmoplegi. I tillegg var sykehistorien kort, slik at ytterligere symptomforverring kunne forventes. Derfor ble pasienten testet for antistoffer mot GQ1b, som er til stede hos $85-90 \%$ av pasienter med Miller-Fishers syndrom $(5,6)$.

Dagen etter innleggelsen var jenta uttalt sliten og holdt seg stort sett til sykesengen. Hun klarte ikke å gå uten støtte på grunn av ustøhet og problemer med koordinering. Tredje innleggelsesdøgn oppsto en høyresidig perifer facialisparese, og pasienten anga nummenhet omkring munnen samt tann- og kjevesmerter som tidligere. De neste dagene utviklet hun nedsatt hørsel bilateralt. Ny klinisk undersøkelse avdekket symmetrisk nedsatt muskeltonus og nedsatt kraft i over-og

\author{
Katrine Gauer \\ katrine.gauer@so-hf.no \\ Kjell-Ivar Helgestad \\ Christian Wirsching \\ Barneavdelingen \\ Sykehuset Østfold Fredrikstad \\ Ketil Størdal \\ Sykehuset Østfold Fredrikstad \\ og \\ Divisjon for epidemiologi \\ Nasjonalt folkehelseinstitutt
}

Se kommentar side 426 


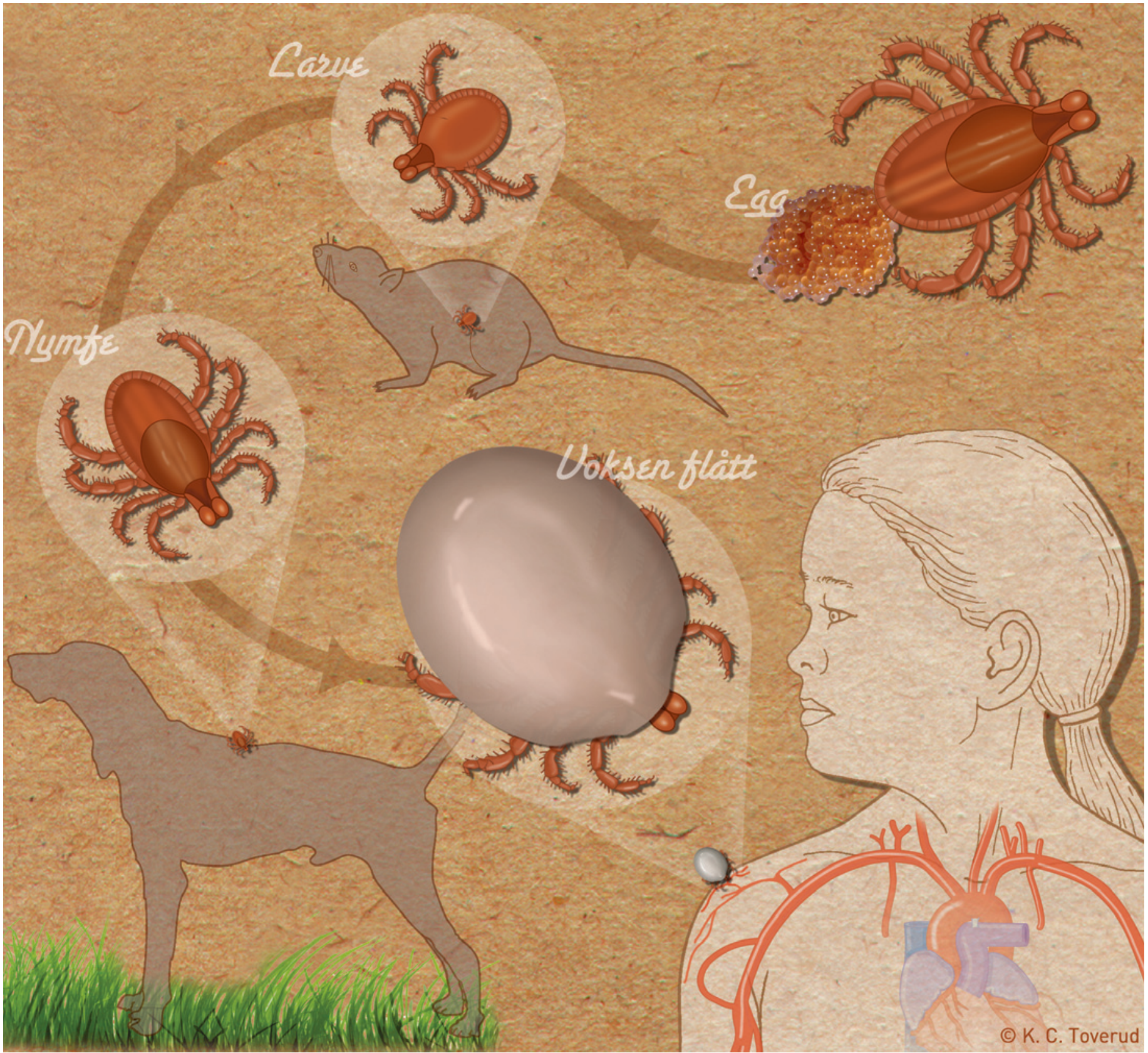

Flåttens livssyklus

underekstremiteter, spesielt for fingerspriking og fingerekstensjon. Vi fant lettgradig dysmetri ved finger-nesetipp-test, moderat ataksi i underekstremitetene og utslukkede reflekser i over-og underekstremiteter med indifferent plantarrefleks bilateralt.

Guillain-Barrés syndrom er den vanligste årsaken til akutt paralyse hos tidligere friske barn (8). Den estimerte insidensen er på 1-4 tilfeller/100 000 årlig hos voksne og noe sjeldnere hos barn $(6,8)$. Det er en alvorlig sykdom, med 3-10\% mortalitet (6). Syndromet ble tidligere oppfattet som én sykdom, men det er nå avdekket flere varianter (6). Miller-Fishers syndrom utgjør ca. $5 \%$ av pasientene med GuillainBarrés syndrom $(6,8)$. Intravenøs immun- globulin og plasmaferese er vist å redusere varighet og alvorlighetsgrad av sykdommen $(5,6,9)$.

Den klassiske presentasjonsformen for Guillain-Barrés syndrom hos voksne er akutt innsettende nummenhetsfølelse $i$ tær og fingre etterfulgt av symmetrisk svakhet $i$ beina som brer seg proksimalt. Klinisk undersøkelse vil avdekke reduserte eller utslukkede dype senereflekser $(6,8)$. Barn med syndromet har ofte en annen klinisk debut enn voksne, med smerter og gangforstyrrelser som dominerende symptomer (10). Nesten $70 \%$ av pasientene har hatt en infeksjon i øvre luftveier og/eller gastrointestinalkanalen før symptomdebut (8). Nesten halvparten utvikler autonome dysfunksjoner, og noen utvikler også kranial nevropati $(6,8)$.
Pasienten ble undersøkt med elektromyografi (EMG), der alle resultater var innenfor normalområdet. Nevrografi avdekket forlengede F-responser/vanskelig påvisbare $F$-responser. Det var ingen forandringer for sensoriske fibre, og for motoriske fibre kun lett forlenget distal latenstid for peroneus på venstre side.

Det er vanlig å utføre EMG/nevrografi og spinalvæskeundersøkelse i utredningen av Guillain-Barrés syndrom. Forlengede distale latenstider og patologiske F-responser ved nevrografi reflekterer demyelinisering og indikerer involvering av proksimale nerverøtter. Dette er det mest sensitive og spesifikke laboratoriefunnet ved syndromet (6, 8 ). Normale elektrofysiologiske funn taler 
imot diagnosen (8). De nevrofysiologiske kriteriene for å stille en sikker diagnose var ikke til stede hos vår pasient, men en atypisk variant av Guillain-Barrés syndrom, som akutt motorisk aksonal nevropati (AMAN) eller Miller-Fishers syndrom, kunne heller ikke utelukkes $(6,8)$.

Parallelt med den nevrofysiologiske utredningen ble det tatt blodprøver av pasienten for å undersøke om symptomene kunne skyldes mykoplasma-, chlamydia- eller hivinfeksjon. Det ble startet behandling med erytromycin med tanke på mykoplasmainfeksjon i sentralnervesystemet. Det ble også tatt blodprøver for å se etter angiotensinkonvertasehemmere (ACE) i serum, som ved sarkoidose, og en serumprøve ble sendt til Nasjonalt folkehelseinstitutt for å undersøke for skogflåttencefalitt.

Normalt celletall med økt protein i spinalvæsken innen 1-2 uker etter symptomdebut er karakteristisk for Guillain-Barrés syndrom (8). $80-90 \%$ av voksne pasienter med syndromet har normalt celletall i spinalvæsken en uke etter symptomdebut (6). Pleocytose $>50$ celler er så uvanlig at andre aktuelle diagnoser må vurderes, slik som nevroborreliose, hiv, neoplasi, toksisk nevropati, europeisk skogflåttencefalitt og herpesvirus 1 og $2(6,9,11)$. I to prospektive studier av henholdsvis $42 \mathrm{og}$ 52 barn med Guillain-Barrés syndrom fant man fra 0-60 celler/ $\mu \mathrm{l}$ i spinalvæsken, der henholdsvis $59,5 \%$ og $50 \%$ av barna hadde $<5$ celler og gjennomsnittet var henholdsvis 6 og 18 celler $(12,13)$. Det klart forhøyede celletallet hos vår pasient gjorde diagnosen Guillain-Barrés syndrom lite sannsynlig.

Etter hvert som pasientens symptomer tiltok, diskuterte vi hvorvidt intravenøs immunglobulin kunne være et aktuelt behandlingsalternativ. Med bakgrunn i den uavklarte diagnosen og med funn som ikke var typisk for Guillain-Barrés syndrom, var vår vurdering at det ikke var behandlingsindikasjon på dette tidspunktet.

Skogflåttencefalitt er en flåttbåren sykdom med varierende klinisk bilde som er endemisk i deler av Sverige (11). Kriterier for laboratoriebekreftelse av diagnosen er enten påvisning av skogflåttencefalittvirus ved dyrking eller polymerasekjedereaksjonstest (PCR), eller spesifikke antistoffer mot skogflåttencefalittvirus i serum og/eller spinalvæske $(14,15)$. IgG-serokonversjon regnes som sikkert, og likedan titerstigning til over fire ganger utgangsnivå $(14,15)$. Kliniske symptomer og funn forenlig med skogflåttencefalitt må være til stede for at diagnosen kan stilles $(14,15)$. Vår pasient hadde ikke reist utenfor eget fylke de siste tre månedene før det aktuelle, men ettersom symptomer og forløp var forenlige med sykdommen, tok man allikevel prøver med tanke på denne diagnosen.
Femte innleggelsesdøgn hadde pasienten fortsatt en uavklart tilstand med stadig progredierende symptomer og ble derfor overført til universitetssykehus for videre utredning. Ifølge epikrisen fra oppholdet der utviklet hun økende hjernenervepareser, med bilateral facialisparese. Hun anga dårligere hørsel, påvirket svelgfunksjon og nedsatt hostekraft. Behandlingen med ceftriakson, aciklovir og erytromycin ble videreført, og pasienten ble observert på intensivavdeling med tanke på risiko for autonome forstyrrelser. Ny MR-undersøkelse av hele sentralnervesystemet ble utført med kontrast. Det ble avdekket patologisk kontrastoppladning i flere hjernenerver i bakre skallegrop med relativt symmetrisk utbredelse samt kraftig kontrastoppladning $i$ ventrale og dorsale conusnerverøtter, kaudale røtter og leptomeningealt rundt conus. Audiometri avdekket bilateral hørselsnedsettelse.

I utredningen av Guillain-Barrés syndrom kan det være aktuelt å utføre MR-undersøkelse med kontrast av ryggmargen, for eksempel for å utelukke transvers myelitt (16). Ved syndromet vil MR med kontrast ofte vise oppladning av spinale nerverøtter og cauda equina, da oftest de ventrale nerverøtter. Dette er imidlertid uttrykk for en forstyrrelse i blod-nerve-barrieren som følge av en inflammasjon og ikke et spesifikt funn for Guillain-Barrés syndrom (16).

Ved universitetssykehuset ble det gjort omfattende prøvetaking med tanke på aktuell infeksiøs årsak og det ble testet for blant annet Epstein-Barr-virus, enterovirus, herpes simplex-virus, varicella zoster-virus, rota- og adenovirus samt borreliaantistoff alt med negativt resultat. Isoelektrisk fokusering av serum og spinalvæske viste ingen oligoklonale lgG-bånd. Gjentatt spinalvæskeundersøkelse dag 6 etter innleggelse viste 425 celler $(\leq 4 / \mu l)$ totalprotein 3,37 (0,15-0,45 $\mathrm{g} / \mathrm{ll}$ og normal glukose. Plasmaferese ble vurdert, men etter to dager med intravenøs immunglobulin snudde tilstanden. Pasienten ble gradvis bedre med økende kraft i beina og tilbakegang av sensibilitetstap.

Pasientens symptomer og spinalvæskefunn ved innleggelse ved vårt sykehus var forenlige med nevroborreliose. Behandling med antibiotika vil vanligvis gi rask symptomlindring med målbar effekt på celletall i spinalvæsken (17). Det ble startet opp intravenøs antibiotika mot nevroborreliose allerede første innleggelsesdøgn, men allikevel økte pasientens symptomer den påfølgende uken og det var stigning i celletall i spinalvæske fra 351 til 425 . Videre var gjentatte prøver på borreliaantistoff negative. Nevroborreliose var dermed lite sannsynlig.

Pasienten ble flyttet tilbake til vårt sykehus med diagnosen uspesifisert polynevropati etter ni dager ved universitetssykehuset.
Ved klinisk undersøkelse hadde hun nå nedsatt hørsel, dobbeltsyn, bilateral facialisparese, nedsatt sensibilitet $i$ begge underekstremiteter, nedsatt kraft ved dorsalfleksjon av ankelledd bilateralt, utslukkede patellarog akillesreflekser og indifferent plantarrefleks bilateralt. Hun holdt fremdeles sengen, var sliten, preget av angst og fremsto tidvis forvirret ved at hun gjentok egne spørsmål og glemte beskjeder.

Alle prøvesvar hadde så langt vært negative, inkludert test for antistoffer mot GQ1b. 14 dager etter første innleggelse kom det svar fra Nasjonalt folkehelseinstitutt. Serumprøven tatt tidlig i forløpet var positiv for IgM-antistoffer mot skogflåttencefalittvirus (tickborne encephalitis virus, TBEV) og negativ for IgG-antistoffer. Kontrollprøve tatt 21 dager senere viste signifikant titerstigning av anti-TBE-IgM samt serokonversjon til anti$T B E-\lg G$, forenlig med aktuell infeksjon.

Dette er det første rapporterte tilfellet av skogflåttencefalitt $\mathrm{i}$ vårt fylke $(11,18)$. Vår pasient viste gradvis bedring og ble utskrevet etter fire uker på sykehus. Deretter ble hun fulgt opp poliklinisk $i$ et halvt år. De første månedene etter utskrivning var hun preget av utmattelse og konsentrasjonsproblemer, men er i dag helt frisk. Folkehelseinstituttet vil nå undersøke forekomsten av henholdsvis TBE-virus hos flått og antistoffer mot TBE-virus hos blodgivere $\mathrm{i}$ vårt fylke. Resultatene vil danne grunnlag for fremtidige vaksineanbefalinger (11).

\section{Diskusjon}

Skogflåttencefalitt er en flåttbåren infeksjonssykdom som rammer sentralnervesystemet (11). Den forårsakes av et flavivirus kalt skogflåttencefalittvirus. I Norge er flåtten Ixodes ricinus potensiell bærer både av Borrelia burgdorferi som forårsaker Lymeborreliose og av skogflåttencefalittviruset. Sykdommen er endemisk i store deler av Sentral-, Øst- og Nord-Europa. I Skandinavia er sykdommen endemisk i kystområdene rundt Østersjøen i Sverige (11). Det er også rapportert tilfeller av skogflåttencefalitt på vestkysten av Sverige sør for Göteborg opp til de nordre deler av Bohuslän (19). I Norge er det bekreftet at skogflåttencefalitt forekommer i kystområdene vest for Oslofjorden, med høyest forekomst i Agder-fylkene (11).

Det første tilfellet av skogflåttencefalitt smittet i Norge er fra Tromøy i 1997 (18). Ifølge Nasjonalt folkehelseinstitutt er det frem til og med 2010 mottatt 54 meldinger der pasienten er antatt smittet i Norge, hvorav åtte har vært i alder 0-19 år (11).

Skogflåttencefalitt er et aktuelt helsetema internasjonalt fordi antall risikoområder og rapporterte tilfeller i Europa, Russland og deler av Asia fortsetter å øke (14). I Europa har man sett en økning i rapporterte tilfeller på $400 \%$ i løpet av de siste tiårene (14). Flåttaktiviteten er temperaturavhengig, og 
skogflåttencefalitt er derfor sesongrelatert til perioden april-november $(11,14)$.

Skogflåttencefalitt har en inkubasjonstid på 2-28 dager etter bittet $(14,18,20)$. Bifasisk forløp ses hos ca. ni av ti voksne pasienter, men er mindre vanlig hos barn $(14,18$, 20). Første fase karakteriseres av uspesifikke symptomer som hodepine, muskelsmerter og feber av 1-8 dagers varighet. Etter en symptomfri periode på ca. én uke utvikler en av tre pasienter symptomer på meningitt eller meningoencefalomyelitt av varierende alvorlighetsgrad (11). Det er stor variasjon i det kliniske bildet fra asymptomatisk til alvorlig sykdom. Barn har vanligvis et mildere forløp med god prognose sammenliknet med voksne (14). Letaliteten i Vest-Europa er under $1 \%$, ca. $3 \%$ av voksne smittede får permanente pareser og ca. $30 \%$ utvikler postencefalittsyndrom $(11,14)$

Det finnes ingen behandling mot skogflåttencefalitt. Vaksinen mot skogflåttencefalitt gir, ifølge Folkehelseinstituttet, beskyttelse hos $95 \%$ etter fullført grunnvaksinasjon, som består av tre doser som gis i løpet av et år (11). En oppfriskningsdose kan gis etter tre år, deretter hvert 3.-5. år, som et tillegg til grunnvaksinasjonen ved behov for videre beskyttelse (11). I Norge bør vaksinen vurderes til personer som ofte blir bitt av flått der det er kjent forekomst av skogflåttencefalittvirus.

Ved gjennomgang av litteraturen finnes få studier på skogflåttencefalitt hos barn. Det er behov for prospektive studier for å få bedre kjennskap til det naturlige sykdomsforløp hos barn, med insidens, morbiditet og prognose $(14,21)$. Det er vist at både alvorlig forløp av skogflåttencefalitt og permanente nevrologiske sekveler kan forekomme hos barn $(20,22)$.

I en retrospektiv analyse av 116 barn innlagt med skogflåttencefalitt hadde $65 \%$ bifasisk forløp, med symptomfritt intervall 2-18 dager (20). Så mange som halvparten av barna med meningoencefalitt var somnolente. Vår pasient opplevde smerteplager i en slik grad at hun søkte hjelp hos tannlege og fastlege. Deretter var hun symptomfri i to dager før hun ble akutt syk med nevrologiske symptomer. Under oppholdet på barneavdelingen fremsto pasienten svært sliten, tidvis forvirret og preget av angst. Hun holdt sengen og sov mye også på dagtid. Dette kunne være en følge av hørselstapet og den generelle sykdomspåvirkningen, men kognitiv påvirkning som ved en encefalittilstand er også en mulig forklaring.

Hansson og medarbeidere evaluerte retrospektivt 3635 anti-TBE-serumprøver, hvorav 699 fra barn under 16 år i Stockholm (14). De fant at uspesifikke influensaliknende symptomer ved skogflåttencefalitt var vanligere hos barn enn voksne og at bifasisk forløp var mindre hyppig jo yngre barnet var (14). Sundin og medarbeidere gjennomførte en prospektiv studie med varighet på ett år av 124 barn med nevrologiske symptomer i Stock- holm (21). De fant ti barn (8,1\%) med skogflåttencefalitt, hvilket ga en estimert insidens på 10/100 000 per år, mot tidligere antatt insidens på 4/100 000 per år. Slike funn gir grunn til å mistenke at skogflåttencefalitt er underdiagnostisert hos barn. Dette kan være fordi det naturlige sykdomsforløpet ofte er mildt og skiller seg fra skogflåttencefalitt hos voksne (14).

Selv om skogflåttencefalitt ikke kan behandles, vil diagnostisering av sykdommen være nyttig for å forklare pasientens symptomer og for å kartlegge behov for oppfølging. Sykdommen er nominativt meldepliktig til Meldingssystem for smittsomme sykdommer (MSIS), og meldingene bidrar til å danne grunnlag for Folkehelseinstituttets vaksineanbefalinger.

Sykehistorien illustrerer betydningen av klinisk årvåkenhet og faglig kjennskap til uvanlige sykdommer. Den viser også betydningen av å gjenta kliniske undersøkelser og revurdere tentative diagnoser underveis $i$ sykdomsforløpet.

Pasienten og pasientens foresatte har gitt samtykke til at artikkelen blir publisert.

Vi takker Kirsti Vainio og Susanne G. Dudman ved Nasjonalt folkehelseinstitutt for laboratoriediagnostikk av skogflåttencefalitt og verdifulle kommentarer vedrørende dette, Marit Valen og Anne Kristine Lossius ved Halmstad legekontor i Rygge for godt samarbeid og overlege Inger Sandvig ved Rikshospitalet for verdifullt bidrag.

\section{Katrine Gauer (f. 1979)}

er lege i spesialisering ved barneavdelingen. Forfatter har fylt ut ICMJE-skjemaet og oppgir ingen interessekonflikter.

\section{Kjell-Ivar Helgestad (f. 1972)}

er fastlege i Hvaler kommune. Han har jobbet et år som lege i spesialisering ved barneavdelingen.

Forfatter har fylt ut ICMJE-skjemaet og oppgir ingen interessekonflikter.

\section{Christian Wirsching (f. 1978)}

er fastlege i Gjerdrum kommune. Han har jobbet som lege i spesialisering ved barneavdelingen.

Forfatter har fylt ut ICMJE-skjemaet og oppgir ingen interessekonflikter.

\section{Ketil Størdal (f. 1966)}

er spesialist i pediatri og dr.med. med pediatrisk gastroenterologi som hovedfelt, og er overlege.

Forfatter har fylt ut ICMJE-skjemaet og oppgir ingen interessekonflikter.

\section{Litteratur}

1. Florance NR, Davis RL, Lam C et al. Anti-Nmethyl-D-aspartate receptor (NMDAR) encephalitis in children and adolescents. Ann Neurol 2009 66: $11-8$.
2. Vincent A, Bien CG Anti-NMDA-receptor encephalitis: a cause of psychiatric, seizure and movement disorders in young adults. Lancet Neurol 2008; 7: 1074-5.

3. Slettedal IO, Dahl HM, Sandvig I et al. Ung jente med psykose, kognitiv svikt og kramper. Tidssk Nor Legeforen 2012; 132: 2073-6.

4. Jørgensen L, Vedeler CA. Miller-Fishers syndrom. Tidsskr Nor Lægeforen 2005; 125: 1327-8.

5. Asbury AK. New concepts of Guillain-Barre syndrome. J Child Neurol 2000; 15: 183-91.

6. Hughes RAC, Cornblath DR. Guillain-Barré syndrome. Lancet 2005: 366: 1653-66.

Whitesell J. Inflammatory neuropathies. Semin Neurol 2010; 30: 356-64.

8. Ropper AH. The Guillain-Barré syndrome. N Engl J Med 1992; 326: 1130-6.

9. Marks D, Jann A, DeAngelis T. Clinical reasoning: a middle-aged woman with progressive symmetric weakness and a CSF pleocytosis. Neurology 2012; 78: e88-92

10. Pier DB, Hallbergson A, Peters JM. Guillain-Barré syndrome in a child with pain: lessons learned from a late diagnosis. Acta Paediatr 2010; 99. 1589-91.

11. Smittevernboka. Skogflåttencefalitt. www. fhi.no/eway/default.aspx? pid=233\&trg= MainLeft 6039\&MainArea 5661=6039:0:15,5078: 1:0:0:0:0\&MainLeft_6039=6041:82867:1:6043. 107:0:0 (23.7.2012)

12. Koul RL, Alfutaisi A. Prospective study of children with Guillain-Barre syndrome. Indian J Pediatr 2008. 75. 787-90.

13. Koul R, Chacko A, Ahmed R et al. Ten-year prospective study (clinical spectrum) of childhood Guillain-Barré syndrome in the Arabian peninsula: comparison of outcome in patients in the preand post-intravenous immunoglobulin eras. J Child Neurol 2003; 18: 767-71.

14. Hansson MEA, Örvell C, Engman M-L et al. Tickborne encephalitis in childhood: rare or missed? Pediatr Infect Dis J 2011; 30: 355-7.

15. Holzmann H. Diagnosis of tick-borne encephalitis. Vaccine 2003; 21 (suppl 1): S36-40

16. Mulkey SB, Glasier CM, El-Nabbout B et al. Nerve root enhancement on spinal MRI in pediatric Guillain-Barré syndrome. Pediatr Neurol 2010; 43 : 263-9.

17. Mygland $\AA$. Når røde flagg blafrer, men blodprøve og MR er normale. Tidsskr Nor Legeforen 2011 131: 961

18. Skarpaas T, Sundøy A, Bruu AL et al. Skogflåttencefalitt i Norge. Tidsskr Nor Lægeforen 2002; 122 $30-2$.

19. Smittskyddsinstitutet. Epidemiologisk årsrapport 2011. TBE-infektion.

www.smittskyddsinstitutet.se/publikationer/ arsrapporter-och-verksamhetsberattelser/ smis-epidemiologiska-arsrapporter/ epidemiologisk-arsrapport-2011/ (20.11.2012).

20. Fritsch P, Gruber-Sedlmayr U, Pansi H et al. Tickborne encephalitis in Styrian children from 1981 to 2005: a retrospective study and a review of the literature. Acta Paediatr 2008; 97: 535-8.

21. Sundin $M$, Hansson MEA, Engman $M-L$ et al. Pediatric tick-borne infections of the central nervous system in an endemic region of Sweden: a prospective evaluation of clinical manifestations. Eur J Pediatr 2012; 171: 347-52.

22. Schmolck H, Maritz E, Kletzin I et al. Neurologic, neuropsychologic, and electroencephalographic findings after European tick-borne encephalitis in children. J Child Neurol 2005; 20: 500-8.

Mottatt 11.5. 2012, første revisjon innsendt 11.9. 2012, godkjent 20.12. 2012. Medisinsk redaktør Merete Kile Holtermann. 